\title{
PENGARUH GAYA KEPEMIMPINAN, MOTIVASI DAN LOYALITAS TERHADAP KINERJA KARYAWAN
}

\author{
Oleh: \\ Arief Teguh Nugroho \\ Sekolah Tinggi Ilmu Ekonomi Pelita Bangsa, Bekasi1) \\ ariefteguhnugroho@gmail.com ${ }^{1)}$
}

\begin{abstract}
ABSTRAK
Penelitian bertujuan untuk menganalisis pengaruh gaya kepemimpinan, motivasi dan loyalitas kerja terhadap kinerja karyawan.

Penelitian dilakukan pada CV Anugerah. Penelitian menggunakan 40 sampel penelitian yang merupakan anggota dari seluruh populasi. Data penelitian diperoleh dengan instrument kuesioner. Data hasil penelitian dianalisis menggunakan analisis desktiptif dan verifikatif.

Penelitian menghasilkan model persamaan regresi linier ganda $\hat{Y}=1.428-0,238 X 1+0,312 X 2+$ 0.507X3 dimana Gaya Kepemimpinan, Motivasi dan Loyalitas Kerja mampu menjelaskan 37,30\% variabilitas Kinerja karyawan. 1) Gaya Kepemimpinan tidak berpengaruh terhadap Kinerja; artinya baik buruknya gaya kepemimpinan tidak akan menyebabkan terjadinya perubahan pada kinerja karyawan. 2) Motivasi memiliki pengaruh terhadap Kinerja dengan arah positif; artinya makin tinggi Motivasi maka makin tinggi pula Kinerja karyawan. 3) Loyalitas Kerja memiliki pengaruh terhadap Kinerja dengan arah positif; artinya makin tinggi Loyalitas kerja maka makin tinggi pula Kinerja karyawan CV Anugerah.
\end{abstract}

\section{Kata kunci:}

Gaya Kepemimpinan, Motivasi, Loyalitas Kerja, Kinerja Karyawan

\section{PENDAHULUAN}

Sumber Daya Manusia menempati prioritas utama karena memiliki sifat tersendiri. Pengelolaan SDM dalam organisasi haruslah memiliki dasar dan arah yang jelas, sehingga kesinambungan dan keselarasannya terjamin. Hal itu dapat terjadi apabila perencanaan, pelaksanaan dan pengawasannya dilakukan sebaikbaiknya, sehingga pada akhirnya dapat mendukung tujuan perusahaan. SDM yang sehat jasmani rohani, berbudi luhur dan berkualitas, dipandang sebagai unsur yang sangat menentukan dalam proses pengembangan usaha. Oleh sebab itu salah satu fungsi manajemen SDM adalah merekrut, membina dan mengembangkan SDM agar terdapat kualitas yang sesuai dengan kebutuhan organisasi.

Dalam organisasi, bawahan bekerja selalu tergantung pada pimpinan. Bila pimpinan tidak memiliki kemampuan memimpin, maka tugas yang sangat kompleks tidak dapat dikerjakan dengan baik. Apabila semua level karyawan mampu melaksanakan fungsinya dengan 
baik, sangat mungkin organisasi tersebut dapat mencapai sasarannya. Suatu organisasi membutuhkan pemimpin yang efektif, yang mempunyai kemampuan mempengaruhi perilaku anggotanya atau anak buahnya (Alimuddin, 2002). Jadi, seseorang pemimpin atau kepala suatu organisasi akan diakui sebagai seorang pemimpin apabila ia dapat memberi pengaruh dan mampu mengarahkan bawahannya ke arah tujuan organisasi.

Kepemimpinan merupakan salah satu isu dalam manajemen yang menarik untuk diperbincangkan. Media masa, baik elektronik maupun cetak, seringkali menampilkan opini dan pembicaraan yang membahas seputar kepemimpinan. Peran kepemimpinan yang sangat strategis dan penting bagi pencapaian misi, visi dan tujuan organisasi, merupakan salah satu motif yang mendorong manusia untuk selalu menyelidiki seluk-beluk yang terkait dengan kepemimpinan.

Kualitas dari kepemimpinan seringkali dianggap sebagai faktor terpenting dalam keberhasilan atau kegagalan organisasi (Bass, 1990, dalam Menon, 2002). Demikian juga keberhasilan atau kegagalan suatu organisasi dipersepsikan sebagai keberhasilan atau kegagalan pemimpin. Begitu pentingnya peran pemimpin sehingga isu mengenai pemimpin menjadi fokus yang menarik perhatian para peneliti bidang perilaku keorganisasian.

Pemimpinan memegang peran kunci dalam memformulasikan dan mengimplementasikan strategi organisasi (Su'ud, 2000). Hal ini membawa konsekuensi bahwa setiap pimpinan berkewajiban memberikan perhatian sungguh-sungguh untuk membina, menggerakkan, mengarahkan semua potensi karyawan dilingkungannya agar terwujud volume dan beban kerja yang terarah pada tujuan (M. Thoha, 2001).
Organisasi dalam mencapai tujuan dan memenuhi tanggung jawab sosialnya sangat tergantung pada para pimpinan. Bila pimpinan mampu melaksanakan dengan baik, sangat mungkin organisasi tersebut akan mencapai sasarannya. Suatu organisasi membutuhkan pemimpin yang efektif, yang mempunyai kemampuan mempengaruhi perilaku anggotanya atau anak buah. Jadi, seorang pemimpin atau kepala suatu organisasi akan diakui sebagai seorang pemimpin apabila ia dapat mempunyai pengaruh dan mampu mengarahkan bawahannya kearah pencapaian tujuan organisasi.

Setiap pimpinan di lingkungan organisasi kerja, selalu memerlukan sejumlah karyawan sebagai pembantunya dalam melaksanakan tugas-tugas yang menjadi volume dan beban kerja unit masing-masing. Hal ini membawa konsekuensi bahwa setiap pimpinan berkewajiban memberikan perhatian yang sungguh-sungguh untuk membina, menggerakkan dan mengarahkan semua potensi karyawan di lingkungannya agar terwujud volume dan beban kerja yang terarah pada tujuan (Marzuki, 2002). Pimpinan perlu melakukan pembinaan yang sungguh-sungguh terhadap karyawan di lingkungannya agar dapat meningkatkan kepuasan kerja, komitmen organisasi dan kinerja yang tinggi.

Gaya kepemimpinan adalah suatu cara yang digunakan oleh seorang pemimpin dalam mempengaruhi perilaku orang lain. Gaya kepemimpinan merupakan norma perilaku yang digunakan oleh seseorang pada saat orang tersebut mencoba mempengaruhi perilaku orang lain. Masing-masing gaya tersebut memiliki keunggulan dan kelemahan. Seorang pemimpin akan menggunakan gaya kepemimpinan sesuai kemampuan dan kepribadiannya (Marzuki, 2002). 
Setiap pemimpin dalam memberikan perhatian untuk membina, menggerakan dan mengarahkan semua potensi karyawan di lingkungannya memiliki pola yang berbeda-beda antara satu dengan yang lainnya. Perbedaan itu disebabkan oleh gaya kepemimpinan yang berbedabeda pula dari setiap pemimpin. Kesesuaian antara gaya kepemimpinan, norma-norma dan kultur organisasi dipandang sebagai suatu prasyarat kunci untuk kesuksesan prestasi tujuan organisasi. Tampubolon (2007) telah meneliti pengaruh gaya kepemimpinan terhadap kinerja, menyatakan bahwa gaya kepemimpinan mempunyai pengaruh yang signifikan terhadap kinerja karyawan.

Salah satu upaya yang dilakukan pemimpin dalam upaya meningkatkan peran serta karyawan adalah dengan meningkatkan loyalitas kerja dan motivasi kerja karyawan. Loyalitas kerja karyawan merupakan suatu kesetiaan kepada instansi tempat dimana dia bekerja dengan baik sesuai peraturan, ada hak ada kewajiban. Loyalitas merupakan kualitas perasaan, dan perasaan tak selalu membutuhkan penjelasan rasional.

Motivasi kerja merupakan suatu proses psikologis yang mencerminkan interaksi antara sikap, kebutuhan, persepsi dan kepuasan yang terjadi pada setiap orang. Untuk dapat meningkatkan motivasi terhadap peningkatan kinerja karyawan pada suatu instansi, maka seorang pemimpin harus menyadari pentingnya peran unsur manusia selaku anggota organisasi benar-benar menjadi salah satu kunci keberhasilan untuk mempengaruhi motivasi terhadap kinerja yang pada akhirnya pencapaian keberhasilan misi instansi.

Bertahannya sebuah imperium bisnis, tidak melulu terletak pada keuntungan. Tapi seutuhnya keuntungan itu hanyalah hasil utama yang diupayakan karyawan, seperti halnya prajurit bagi sebuah negara. Negara akan bertahan dari serangan musuh, bukan karena presidennya semata, tapi karena prajurit yang mau mati dan menjadi martir di medan perang.

Memahami bahwa karyawan adalah bagian terpenting bagi pencapaian kejayaan perusahaan, sama halnya menganggap penting akan keuntungan dan surplus yang layak diraih perusahaan. Tumbuhnya sebuah imperium bisnis tidak terlepas dari kepemimpinan terhadap karyawan. Daya motivasi menggerakan karyawan pada posisi yang sesuai dengan kemampuan dan keahlian yang dimiliki adalah pilar penting dalam menjalankan visi perusahaan. Beberapa peneliti telah menguji hubungan antara motivasi dengan kinerja karyawan Hakim (2006). Pengaruh motivasi kerja terhadap kinerja menunjukan hasil yang sama bahwa hubungan antara motivasi dengan kinerja karyawan menunjukan hubungan positif dan signifikan.

Berdasarkan penelitian pendahuluan di CV Anugerah, peneliti menemukan adanya gaya kepemimpinan yang ada tidak menimbulkan hasil yang optimal, sedangkan motivasi dan loyalitas yang dimiliki oleh karyawan yang cukup tinggi dapat menimbulkan hasil yang optimal. Sehingga timbul pemikiran bagaimana keseluruhan faktor tersebut saling berkesinambungan sehingga mempengaruhi kinerja karyawan.

\section{TUJUAN PENELITIAN}

Untuk mengetahui dan menganalisis pengaruh Gaya Kepemimpinan, Motivasi, dan Loyalitas Kerja terhadap Kinerja Karyawan pada CV Anugerah. 


\section{TELAAH LITERATUR DAN PENGEMBANGAN HIPOTESIS \\ Literatur}

Gaya kepemimpinan adalah bagaimana seorang pemimpin melaksanakan fungsi kepemimpinannya dan bagaimana ia dilihat oleh mereka yang berusaha dipimpinnya atau mereka yang mungkin sedang mengamati dari luar (Robert, 1992). James et. al. (1996) mengatakan bahwa gaya kepemimpinan adalah berbagai pola tingkah laku yang disukai oleh pemimpin dalam proses mengarahkan dan mempengaruhi pekerja. Gaya kepemimpinan adalah perilaku dan strategi, sebagai hasil kombinasi dari falsafah, ketrampilan, sifat, sikap, yang sering diterapkan seorang pemimpin ketika ia mencoba mempengaruhi kinerja bawahannya (Tampubolon, 2007).

Menurut Malthis (2001) motivasi merupakan hasrat didalam diri seseorang yang menyebabkan orang tersebut melakukan tindakan. Sedangkan Rivai (2004) berpendapat bahwa motivasi adalah serangakain sikap dan nilai-nilai yang mempengaruhi individu untuk mencapai hal yang spesifik sesuai dengan tujuan individu.

Menurut Reichheld, semakin tinggi loyalitas para karyawan di suatu organisasi, maka semakin mudah bagi organisasi itu untuk mencapai tujuantujuan organisasi yang telah ditetapkan sebelumnya oleh pemilik organisasi (Utomo, 2002).

Beberapa peneliti telah menguji hubungan gaya kepemimpinan, motivasi, loyalitas kerja terhadap kinerja karyawan antara lain: Suharto dan Cahyono (2005) Penelitiannya menghasilkan temuan bahwa terdapat pengaruh positif dan signifikan antara budaya organisasi, kepemimpinan dan motivasi kerja secara individu mampu bersama-sama terhadap kinerja karyawan. Edy Purwanto (2001),
Penelitiannya menghasilkan temuan bahwa: (1) Secara bersama-sama motivasi, dedikasi dan kemampuan berpengaruh positif dan signifikan terhadap kinerja guru, (2) Secara parsial bersama-sama motivasi, dedikasi dan kemampuan berpengaruh positif dan signifikan terhadap kinerja karyawan. Purnomo Budi Setiawan dan Waridin (2006), penelitiannya menghasilkan temuan bahwa terdapat pengaruh secara signifikan loyalitas kerja karyawan dan budaya organisasi secara bersama-sama berpengaruh secara positif terhadap kinerja karyawan.

\section{Pengaruh Gaya Kepemimpinan terhadap Kinerja Karyawan}

Gaya Kepemimpinan merupakan norma perilaku yang digunakan oleh seseorang pada saat orang tersebut mencoba mempengaruhi perilaku orang lain. Atau dapat pula dikatakan bahwa gaya kepemimpinan adalah pola perilaku yang konsisten ditunjukkan dan sebagai yang diketahui oleh pihak lain ketika seseorang berusaha mempengaruhi kegiatan-kegiatan orang lain.

Menurut Fiedler dalam Thoha (2001: 36) kinerja dapat dicapai secara efektif apabila pemimpin dalam organisasi tersebut mengembangkan suatu gaya kepemimpinan kontingensi. Pendekatan kontingensi merupakan pendekatan yang menyatakan bahwa teknik manajemen yang paling baik memberikan kontribusi untuk pencapaian sasaran organisasi mungkin bervariasi dalam situasi atau lingkungan yang berbeda. Pendekatan ini juga disebut pendekatan kontingensi/situasional. Filder berasumsi dalam teori tersebut bahwa cukup sulit bagi seorang pemimpin untuk mengubah gaya kepemimpinan sehingga membuat mereka sukses Gaya Kepemimpinan pada dasarnya menekankan untuk menghargai 
tujuan individu sehingga nantinya para individu akan memiliki keyakinan bahwa kinerja aktual akan melampaui harapan kinerja mereka. Seorang pemimpin harus menerapkan gaya kepemimpinan untuk mengelola bawahannya, karena seorang pemimpin akan sangat mempengaruhi keberhasilan organisasi dalam mencapai tujuannya (Waridin dan Bambang Guritno, 2005). Tampubolon (2007) menyatakan bahwa faktor kepemimpinan juga berpengaruh terhadap kinerja karyawan.

Dari pendapat para ahli tersebut dapat disimpulkan bahwa terdapat hubungan yang erat dan pengaruh antara faktor kepemimpinan dan faktor kinerja karyawan CV Anugerah. Oleh Karena itu diduga bahwa Gaya Kepemimpinan berpengaruh terhadap Kinerja Karyawan pada CV Anugerah.

H1: Motivasi berpengaruh terhadap Kinerja Karyawan pada CV Anugerah.

\section{Pengaruh Motivasi terhadap Kinerja Karyawan}

Suharto dan Cahyono (2005) dan Hakim (2006) menyebutkan ada salah satu faktor yang mempengaruhi kinerja yaitu faktor motivasi, dimana motivasi merupakan kondisi yang menggerakan seseorang berusaha untuk mencapai tujuan atau mencapai hasil yang diinginkan. Rivai (2004) menunjukan bahwa semakin kuat motivasi kerja, kinerja karyawan akan semakin tinggi. Hal ini berarti bahwa setiap peningkatan motivasi kerja karyawan akan memberikan peningkatan yang sangat berarti bagi peningkatan kinerja karyawan dalam melaksanakan pekerjaannya. Oleh Karena itu diduga bahwa Motivasi berpengaruh terhadap Kinerja Karyawan pada CV Anugerah. H2: Motivasi berpengaruh terhadap Kinerja Karyawan pada CV Anugerah.

\section{Pengaruh Loyalitas Kerja terhadap Kinerja Karyawan}

Menurut Pambudi, di masa lalu atau masa sebelumnya, loyalitas para karyawan hanya diukur dari jangka waktu lamanya karyawan tersebut bekerja bagi sebuah organisasi. Namun saat ini, ukuran loyalitas para karyawan telah sedikit bergeser ke arah yang lebih kualitatif, yaitu yang disebut sebagai komitmen. Komitmen itu sendiri dapat diartikan sebagai seberapa besar seseorang mencurahkan perhatian, pikiran dan dedikasinya bagi organisasi selama dia bergabung di dalam organisasi tersebut (Utomo, 2002, p.10). Oleh Karena itu diduga bahwa Loyalitas berpengaruh terhadap Kinerja Karyawan pada CV Anugerah.

H3: Loyalitas berpengaruh terhadap Kinerja Karyawan pada CV Anugerah.

Gambar 1

Kerangka Pemikiran

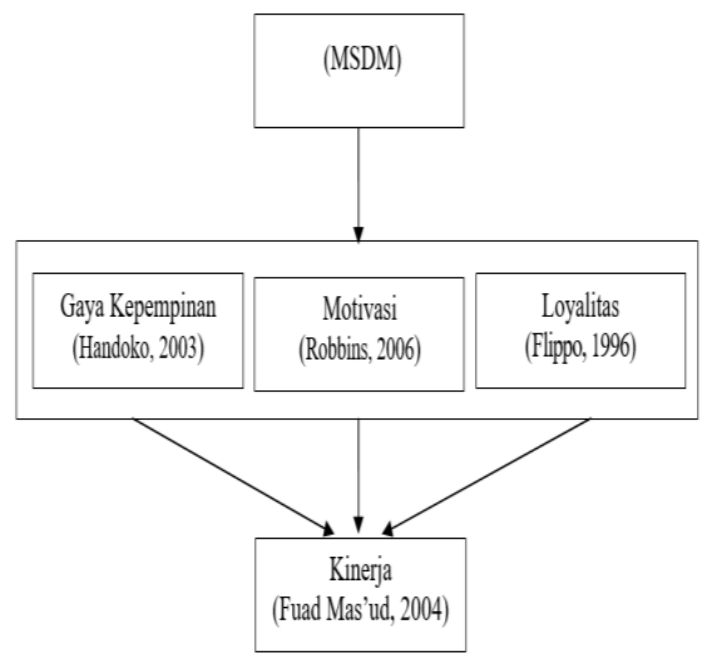

\section{METODE PENELITIAN Tempat Penelitian}

Penelitian ini diadakan pada CV Anugerah. Penelitian dilaksanakan selama 3 (tiga) bulan 
Operasionalisasi Variabel

Tabel 1

Operasionalisasi Variabel

\begin{tabular}{|c|c|}
\hline Variabel & Indikator \\
\hline $\begin{array}{l}\text { Gaya kepemimpinan (Xl) adalah cara pemimpin } \\
\text { memanfaatkan kekuatan yang tersedia untuk } \\
\text { memimpin para karyawannya (Likret, (1961) dalam } \\
\text { Handoko (2003) }\end{array}$ & $\begin{array}{l}\text { 1. Otoriter } \\
\text { 2. Paternalistik. } \\
\text { 3. Konsultatif } \\
\text { 4. Partisipatif }\end{array}$ \\
\hline $\begin{array}{l}\text { Motivasi merupakan factor yang mempengaruhi } \\
\text { semangat dan kegairahaan kerja karyawan kerja } \\
\text { karyawan untuk berperan serta secara aktif dalam } \\
\text { proses kerja. (Maslow, dalam Robbins, 2006) }\end{array}$ & $\begin{array}{l}\text { 1. Fisiologis } \\
\text { 2. Keamanan } \\
\text { 3. Sosial } \\
\text { 4. Penghargaan } \\
\text { 5. Aktualisasi Diri }\end{array}$ \\
\hline $\begin{array}{l}\text { Loyalitas merupakan tekad dan kesanggupan untuk } \\
\text { mentaati, } \text { melaksanakan dan mengamalkan sesuatu } \\
\text { yang ditaati dengan penuh } \square \text { kesadaran dan tanggung } \\
\text { jawab (Flippo, 1996) }\end{array}$ & $\begin{array}{l}\text { 1. Komunikasi } \\
\text { 2. Insentif } \\
\text { 3. Kesejahteraan } \\
\text { 4. Keselamatan Kesehatan Kerja } \\
\text { 5. Hubungan Industrial }\end{array}$ \\
\hline $\begin{array}{l}\text { Kineria Merupakan suatu hasil yang dicapai } \\
\text { oleh karyawan tersebut dalam pekerjaannya } \\
\text { menurut kriteria tertentu yang berlaku untuk suatu } \\
\text { pekerjaan tertentu. (Tsui, Pearce \& Porter, 1997) } \\
\text { dalam Fuad Mas'ud, 2004) }\end{array}$ & $\begin{array}{l}\text { 1. Kuantitas } \\
\text { 2. Kualitas } \\
\text { 3. Efisiensi } \\
\text { 4. Sikap } \\
\text { 5. Standar kualitas }\end{array}$ \\
\hline
\end{tabular}

\section{Sampling}

Populasi adalah keseluruhan kelompok orang, peristiwa, benda, atau obyek lain yang menjadi pusat perhatian peneliti untuk diteliti (Mulyanto dan Wulandari, 2010: 99). Populasi pada penelitian ini adalah karyawan CV Anugerah yang berjumlah 40 orang.

Sampel adalah bagian (subset) dari populasi yaitu sejumlah orang, peristiwa, benda, atau obyek tertentu yang dipilih dari populasi untuk mewakili populasi tersebut (Mulyanto dan Wulandari, 2010: 100). Sampel pada penelitian ini adalah seluruh karyawan CV Anugerah yang berjumlah 40 orang.

Karena seluruh populasi digunakan sebagai sampel penelitian, maka metode pengambilan sampel yang digunakan adalah metode Sampling Jenuh sehingga penelitiannya disebut sebagai sensus.

\section{Metode Pengumpulan Data}

a. Telaah pustaka yang dilakukan dengan mencari landasan teori, penelitian relevan, dan data obyek penelitian khususnya yang berkaitan dengan variabel yang diteliti. Telaah pustaka dilakukan di perpustakaan baik konvensional maupun melalui internet.

b. Observasi yang dilakukan dengan melakukan pengamatan langsung pelaksanaan tugas karyawan baik di kantor CV Anugerah maupun pelaksanaan tugas di lapangan yang berhubungan dengan pihak ketiga maupun obyek lain.

c. Angket (Kuisioner) yang dilakukan dengan menyebarkan daftar pertanyaan kepada responden penelitian mengenai variabel penelitian yaitu Gaya Kepemimpinan, motivasi, dan Loyalitas Kerja Kuisioner disusun dari kisi-kisi instrumentasi variabel berupa kuisioner tertutup.

\section{Metode Analisis}

Analisis yang digunakan dalam penelitian ini adalah deskriptif dan analisis verifikatif yaitu regresi linier ganda. Sebelum analisis regresi linier ganda yang sesungguhnya, dilakukan uji persyaratan analisis yaitu uji asumsi klasik. Uji asumsi klasik digunakan untuk membuktikan bahwa model persamaan regresi linier ganda dapat diterima secara ekonometrika karena memenuhi penaksiran BLUE (Best Linier Unbiased Estimator) artinya penaksiran tidak bias, linier dan konsisten. Uji asumsi terdiri dari uji normalitas, linieritas, multikolinieritas, autokorelasi, dan heteroskedastisitas (Mulyanto dan Wulandari, 2010: 181).

Setelah uji asumsi terpenuhi maka dilakukan analisis regresi linier ganda. Hasil analisis yang utama adalah nilai koefisien korelasi $R$, nilai koefisien determinasi $R$ Square $\left(R^{2}\right)$, dan model persamaan regresi linier ganda:

$$
\mathrm{Y}=\mathrm{a}+\mathrm{b} 1 \mathrm{X} 1+\mathrm{b} 2 \mathrm{X} 2+\mathrm{b} 3 \mathrm{X} 3
$$


Keterangan :

X1 = Gaya Kepemimpinan

X2 = Motivasi

X3 = Loyalitas Kerja

$\mathrm{Y}=$ Kinerja Karyawan

$\mathrm{a}=$ Konstanta

b1 = Koefisien Regresi Gaya

Kepemimpinan

b2 = Koefisien Regresi Motivasi

b3 = Koefisien Regresi loyalitas kerja

\section{HASIL DAN PEMBAHASAN Hasil Penelitian \\ Deskripsi Variabel Penelitian}

- Nilai rata-rata empirik variable gaya kepemimpinan lebih besar daripada nilai tengah teoritik $(3.58>3)$ maka dapat diartikan bahwa Gaya Kepemimpinan cenderung baik.

- Nilai rata-rata empirik variable motivasi lebih besar daripada nilai tengah teoritik $(3.98>3)$ maka dapat diartikan bahwa motivasi cenderung baik.

- Nilai rata-rata empirik variable loyalitas lebih besar daripada nilai tengah teoritik $(3.88>3)$ maka dapat diartikan bahwa loyalitas cenderung baik.

- Nilai rata-rata empirik variable kinerja lebih besar daripada nilai tengah teoritik $(3.78>3)$ maka dapat diartikan bahwa Kinerja cenderung baik.

\section{Uji Asumsi}

Pengujian normalitas secara grafik menghasilkan grafik Normal P-P Plot dari data residual regresi yang dapat dilihat pada gambar dibawah. Grafik tersebut memperlihatkan bahwa sebaran titik-titik nilai residual pada grafik Normal P-P Plot menyebar di sekitar dan mengikuti arah garis diagonal. Hal ini menunjukkan bahwa data variabel yang digunakan untuk analisis regresi ganda berasal dari data yang berdistribusi normal.

Variabel $\mathrm{X} 1$ memiliki nilai tolerance 0,947 dan VIF 1,056, Variabel X2 memiliki nilai tolerance 0,848 dan VIF 1,180 dan Variabel X3 0,862 dan VIF 1,160. Karena nilai Tolerance lebih besar daripada 0.2 dan nilai VIF lebih rendah dari 10 maka dapat disimpulkan bahwa analisis regresi linier ganda tidak memiliki masalah multikolinieritas (model yang dikembangkan sudah tepat).

Nilai Durbin-Watson hasil perhitungan sebesar DW = 1.790. Berdasar kategori yang telah ada, nilai DW termasuk dalam range $1.65<\mathrm{DW}<2.35=$ tidak terjadi autokorelasi. Hal ini dapat disimpulkan bahwa analisis regesi linier ganda yang dilakukan tidak terjadi autokorelasi.

Grafik scatter plot memperlihatkan bahwa titik-titik hasil perhitungan (perpotongan antara nilai residual dan prediksi) relatif menyebar secara acak di atas dan dibawah titik origin serta tidak membentuk pola tertentu. Hal ini dapat dikatakan bahwa analisis regresi ganda $\mathrm{X} 1$, X2 dan X3 terhadap $Y$ benar-benar linier karena tidak memiliki masalah heteroskedastisitas sehingga analisis regresi linier ganda dapat dilanjutkan.

\section{Uji Model}

\section{Tabel 2}

Model Summary Pengaruh Gaya Kepemimpinan, Motivasi dan Loyalitas Kerja Terhadap Kinerja Karyawan

Model Summary

\begin{tabular}{l|c|r|r|r|}
\hline $\begin{array}{l}\text { Mode } \\
\perp\end{array}$ & $R$ & $R$ Square & $\begin{array}{c}\text { Adjusted } R \\
\text { Square }\end{array}$ & $\begin{array}{c}\text { Std. Error of } \\
\text { the Estimate }\end{array}$ \\
\hline 1 & $.649^{2}$ & .421 & .373 & .40645 \\
\hline \multicolumn{4}{|c|}{ a. Predictors: (Constant), $X 3, X 1, \times 2$} \\
b. Dependent Variable: $Y$
\end{tabular}

Sumber: Data penelitian yang diolah, 2017 
Dari tabel tersebut diatas diperoleh nilai koefisien determinasi ganda yang disesuaikan (Adjusted $\mathrm{R}$ Square) sebesar 0.373. Nilai Adj. $R 2=0.373$ menunjukkan bahwa X1, X2 dan X3 dalam model secara bersama-sama mampu menjelaskan $37,30 \%$ variasi $Y$

\section{Tabel 3}

Anova Pengaruh Gaya Kepemimpinan, Motivasi dan Loyalitas Kerja Terhadap Kinerja Karyawan

ANOVA ${ }^{\text {b }}$

\begin{tabular}{|ll|r|r|r|l|l|}
\hline \multicolumn{2}{|c|}{} & \multicolumn{1}{|c|}{$\begin{array}{c}\text { Sum of } \\
\text { Sodel }\end{array}$} & \multicolumn{1}{c|}{ df } & Mean Squares & F & Sig. \\
\hline 1 & Regression & 4.324 & 3 & 1.441 & 8.724 & $.000^{2}$ \\
& Residual & 5.947 & 36 & .165 & & \\
& Total & 10.271 & 39 & & & \\
\hline
\end{tabular}

a. Predictors: (Constant), $\times 3, X 1, \times 2$

b. Dependent Variable: $Y$

Sumber: Data penelitian yang diolah, 2017

Adjusted R Square 0,373 memiliki nilai probabilitas F hitung sebesar 0,000. Karena $\rho$ \# 0 dan probabilitas $F$ hitung lebih kecil daripada taraf uji penelitian (Sig $\mathrm{F}<\alpha$ atau $0,0020<0.05)$, maka model pengaruh Gaya Kepemimpinan, Motivasi dan Loyalitas Kerja terhadap Kinerja Karyawan adalah signifikan.

\section{Analisis Regresi Linier Ganda}

Tabel 4

Koefisien Pengaruh Gaya Kepemimpinan, Motivasi dan Loyalitas Kerja Terhadap Kinerja Karyawan

\begin{tabular}{|c|c|c|c|c|c|c|}
\hline \multicolumn{7}{|c|}{ Coefficients ${ }^{\mathrm{a}}$} \\
\hline \multirow[b]{2}{*}{ Model } & & \multicolumn{2}{|c|}{ Unstandardized Coefficients } & \multirow{2}{*}{$\begin{array}{c}\text { Standardized } \\
\text { Coefficients } \\
\text { Beta }\end{array}$} & \multirow[b]{2}{*}{$t$} & \multirow[b]{2}{*}{ Sig. } \\
\hline & & $B$ & Std. Error & & & \\
\hline 1 & (Constant) & 1.428 & .901 & & 1.585 & .122 \\
\hline & $\mathrm{X} 1$ & .238 & .158 & .196 & $-1,502$ & .142 \\
\hline & $\times 2$ & .312 & .152 & .283 & 2.053 & .047 \\
\hline & $x_{3}$ & .507 & .150 & .463 & 3.390 & .002 \\
\hline
\end{tabular}

Sumber: Data penelitian yang diolah, 2017

Dari tabel di atas dapat disusun model persamaan regresi linier ganda berdasar kolom B sebagai berikut:

$$
\hat{Y}=1.428-0,238 X 1+0,312 X 2+0.507 X 3
$$

Model persamaan regresi linier ganda hasil analisis tersebut dapat diartikan sebagai berikut:

- Koefisien regresi Gaya Kepemimpinan (X1) sebesar b1 $=-0,238$ memiliki nilai probabilitas $\mathrm{t}$ hitung sebesar $-1,502$. Meskipun b1 \# 0 tetapi karena probabilitas $\mathrm{t}$ hitung lebih besar dari pada taraf uji penelitian (Sig $\mathrm{t}>\alpha$ atau $0.142>0.05)$, maka pengaruh Gaya Kepemimpinan (X1) terhadap Kinerja $(Y)$ tidak signifikan.

- Koefisien regresi Motivasi (X2) sebesar $\mathrm{b} 2=0,312$ memiliki nilai probabilitas $\mathrm{t}$ hitung sebesar 2,053. Karena b2 \# 0 dan probabilitas $t$ hitung lebih kecil daripada taraf uji penelitian (Sig $\mathrm{t}<\alpha$ atau 0,047<0.05), maka pengaruh Motivasi (X2) terhadap Kinerja (Y) adalah signifikan.

- Koefisien regresi Displin Kerja (X3) sebesar $b 3=0,507$ memiliki nilai probabilitas $\mathrm{t}$ hitung sebesar 3.390. Karena b3 \# 0 dan probabilitas t hitung lebih kecil daripada taraf uji penelitian (Sig $\mathrm{t}<\alpha$ atau 0,002 < 0.05), maka pengaruh Loyalitas kerja (X3) terhadap Kinerja (Y) adalah signifikan.

\section{Pembahasan}

Pengukuran variabel penelitian dilakukan dengan menggunakan kuisioner yang dikembangkan dari indikator pada masing-masing variabel penelitian. Dari hasil uji validitas terhadap masing-masing variabel penelitian ditemukan bahwa seluruh item pertanyaan pada setiap variabel telah valid. Melalui uji reliabilitas ditemukan bahwa seluruh butir pertanyaan yang telah valid pada masingmasing variabel penelitian dapat dibuktikan reliabilitasnya. Karena kuisioner telah valid dan reliabel maka kuisioner penelitian merupakan alat yang handal untuk mengukur masing-masing variabel penelitian. 
Analisis deskriptif terhadap variabel penelitian menghasilkan temuan yang relatif sama untuk semua variabel penelitian dimana persepsi responden terhadap Gaya Kepemimpinan, Motivasi, Loyalitas Kerja dan Kinerja cenderung baik. Analisis regresi linier ganda telah memenuhi persyaratan analisis dimana analisis yang dilakukan telah memenuhi normalitas, tidak terjadi multikolinieritas, tidak terjadi autokorelasi dan tidak terjadi heteroskedastisitas. Persyaratan analisis regresi linier ganda yang terpenuhi menunjukkan bahwa model persamaan regresi linier ganda yang terbentuk telah memenuhi BLUE (Best Linier Unbiased Estimated). Hal ini menunjukkan bahwa model persamaan regresi linier ganda yang dihasilkan dapat digunakan untuk menjelaskan permasalahan penelitian dan menguji hipotesis penelitian.

Gaya Kepemimpinan, motivasi dan Loyalitas Kerja memiliki pengaruh signifikan terhadap Kinerja, artinya bahwa terdapat pengaruh simultan Gaya Kepemimpinan, Motivasi, dan Loyalitas kerja terhadap Kinerja Karyawan. Pengaruh Gaya kepemimpinan, motivasi dan Loyalitas Kerja terhadap Kinerja ditunjukkan oleh nilai Adjusted R Square = 0,373. Nilai Adjusted R Square tersebut memiliki arti bahwa 37,3\% variasi kinerja karyawan secara bersama-sama dipengaruhi oleh Gaya Kepemimpinan, Motivasi dan Loyalitas Kerja.

Temuan penelitian ini menunjukkan pentingnya Gaya Kepemimpinan, Motivasi dan Loyalitas Kerja dalam mempengaruhi kinerja karyawan. Oleh karena itu, perlu upaya meningkatkan gaya kepemimpinan, motivasi dan loyalitas kerja secara bersama-sama. Upaya tersebut dapat dilakukan dengan jalan memperbaiki setiap variable yang berpotensi mempengaruhi kinerja karyawan khususnya motivasi dan loyalitas karyawan.

Upaya peningkatan secara bersamasama hendaknya diprioritaskan pada peningkatan variable loyalitas kerja yang berdasar analisis regresi linier ganda pengaruhnya lebih besar daripada variable lainnya. Namun demikian, mengingat pengaruhnya secara bersama-sama relative rendah maka perlu diperhatikan potensi variable lain yang dapat mempengaruhi kinerja pegawai seperti budaya organisasi kompensasi, lingkungan kerja, fasilitas kerja, insentif, kedisiplinan dan lain-lain.

\section{Pengaruh Gaya kepemimpinan Terhadap Kinerja}

Gaya Kepemimpinan tidak memiliki pengaruh terhadap Kinerja meskipun Gaya Kepemimpinan memiliki nilai koefisien regresi sebesar b1 $=-0,238$ pada model persamaan regresi linier ganda $\hat{Y}=$ $1.428-0,238 X 1+0,312 X 2+0.507 X 3$. Baik buruknya gaya kepemimpinan tidak akan menyebabkan terjadinya perubahan pada kinerja karyawan.

Hasil penelitian ini tidak sejalan dengan teori maupun temuan penelitian yang dilakukan oleh Rizky Putra (2011) dimana gaya kepemimpinan berpengaruh terhadap kinerja pegawai. Tidak adanya pengaruh gaya kepemimpinan terhadap kinerja karyawan dapat dipahami mengingat kepemimpinan sebaik apapun tidak akan mampu menggerakkan organisasi manakala system yang dibangun tidak mampu memberi landasan bahkan membatasi kreativitas sang pemimpin. Tidak adanya pengaruh gaya kepemimpinan terhadap kinerja karyawan terjadi karena penelitian ini memiliki keterbatasan karakteristik, jumlah dan sebaran responden serta pengukuran variabel. Selain itu, tidak adanya pengaruh gaya kepemimpinan terhadap kinerja mungkin terjadi karena factor yang 
mempengaruhi kinerja bukan gaya kepemimpinannya tetapi sikap, tipe dan perilaku pemimpinnya. Oleh karena itu organisasi perlu melakukan telaah kembali dalam rangka mendapatkan hasil penelitian yang lebih baik agar dapat digeneralisasi dan dapat digunakan dalam pengambilan kebijakan yang lebih baik lagi.

\section{Pengaruh Motivasi terhadap Kinerja}

Motivasi memiliki pengaruh sebesar $\mathrm{b} 2=0,312$ pada model persamaan regresi linier ganda $\hat{Y}=1.428-0,238 \mathrm{X} 1+0,312 \mathrm{X} 2+$ $0.507 \mathrm{X} 3$ terhadap Kinerja dengan arah positif. Makin tinggi Motivasi yang diterima karyawan maka makin tinggi pula Kinerja karyawan.

Hasil penelitian ini sejalan dengan teori maupun temuan penelitian yang dilakukan oleh Rizky Putra (2011) yang menghasilkan temuan bahwa motivasi berpengaruh positif terhadap kinerja. Oleh karena itu untuk mendapatkan kinerja karyawan yang semakin tinggi maka dapat diupayakan dengan memberikan motivasi kepada karyawan. Pemberian motivasi kepada karyawan dapat dilakukan dengan memenuhi kebutuhan karyawan mulai dari pemenuhan kebutuhan Fisiologis, Keamanan, Sosial, Penghargaan dan Aktualisasi Diri.

\section{Pengaruh Loyalitas Kerja terhadap Kinerja Karyawan}

Loyalitas Kerja memiliki pengaruh terhadap Kinerja dengan arah positif sebesar $\mathrm{b} 3=0,507$ pada model persamaan regresi linier ganda $\hat{Y}=1.428-0,238 X 1+$ $0,312 X 2+0.507 X 3$. Makin tinggi Loyalitas kerja yang dimiliki karyawan maka makin tinggi pula Kinerja karyawan.

Hasil penelitian ini sejalan dengan teori maupun temuan penelitian yang dilakukan oleh Wicaksono, Bayu (2012) dimana loyalitas berpengaruh terhadap kinerja karyawan dengan arah positif, artinya makin tinggi loyalitas karyawan maka makin tinggi pula kinerja karyawan. Ketika tekad dan kesanggupan karyawan untuk mentaati, melaksanakan dan mengamalkan sesuatu yang ditetapkan organisasi dengan penuh kesadaran dan tanggung jawab maka karyawan akan dengan senang hati melaksanakan setiap tugas dan memiliki kebanggaan menjadi bagian organisasi sehingga hasil kerjanya menjadi lebih baik dari waktu ke waktu. Oleh karena itu organisasi perlu senantiasa berusaha membangun kesadaran dan tanggung jawab serta kebanggaan karyawan menjadi bagian organisasi. Hal ini dapat dilakukan dengan senantiasa menciptakan Komunikasi yang efektif; memperhatikan Kesejahteraan karyawan, menjaga Keselamatan - Kesehatan kerja; dan menciptakan Hubungan Industrial yang memberikan kenyamanan bagi karyawan.

\section{KESIMPULAN}

Penelitian menghasilkan model persamaan regresi linier ganda $\hat{Y}=1.428$ $0,238 X 1+0,312 X 2+0.507 X 3$ dimana Gaya Kepemimpinan, Motivasi dan Loyalitas Kerja mampu menjelaskan 37,30\% variabilitas Kinerja karyawan.

1. Gaya Kepemimpinan tidak berpengaruh terhadap Kinerja; artinya baik buruknya gaya kepemimpinan tidak akan menyebabkan terjadinya perubahan pada kinerja karyawan.

2. Motivasi memiliki pengaruh terhadap Kinerja dengan arah positif; artinya makin tinggi Motivasi maka makin tinggi pula Kinerja karyawan.

3. Loyalitas Kerja memiliki pengaruh terhadap Kinerja dengan arah positif; artinya makin tinggi Loyalitas kerja maka makin tinggi pula Kinerja karyawan CV Anugerah. 


\section{SARAN}

1. Kinerja karyawan hendaknya senantiasa ditingkatkan melalui berbagai upaya diantaranya melalui perbaikan gaya kepemimpinan, motivasi dan loyalitas karyawan secara bersama-sama dengan prioritas pada perbaikan di sisi karyawan yaitu dengan meningkatkan motivasi dan loyalitas karyawan.

2. Upaya peningkatan kinerja karyawan hendaknya dilakukan dengan memperhatikan factor selain gaya kepemimpinan, motivasi dan loyalitas karyawan yang tidak diteliti pada penelitian ini tetapi memiliki potensi kuat dalam mempengaruhi kinerja karyawan seperti budaya organisasi, iklim dan suasana kerja, kompensasi, kesejahteraan, kedisiplinan, komunikasi, partisipasi dan lain-lain.

3. Organisasi dan peneliti lain diharapkan mengkaji ulang penelitian ini khususnya berkaitan dengan gaya kepemimpinan dalam mempengaruhi kinerja karyawan yang pada penelitian ini pengaruhnya tidak signifikan dan bertentangan dengan teori maupun penelitian sebelumnya.

4. Organisasi dan peneliti lain diharapkan melakukan penelitian lanjutan dengan pengukuran dan variable yang lebih lengkap, obyek penelitian yang lebih luas dan memiliki karakteristik yang berbeda serta permasalahan yang lebih spesifik sehingga diperoleh temuan yang dapat digeneralisasi guna menambah khasanah keilmuan khususnya di bidang manajemen sumber daya manusia.

\section{DAFTAR PUSTAKA}

Alimuddin. (2002). Pengaruh gaya kepemimpinan terhadap kinerja pegawai badan pengawasan daerah kota makassar (tesis tidak diterbitkan). Program Pasca Sarjana, Magister Manajemen Universitas Gajah Mada, Yogyakarta.

Edy Purwanto (2001) Analisis Pengaruh motivasi,dedikasi dan kemampuan profesi terhadap kinerja guru SMU 1 Bantarkawung Kabupaten Brebes Hakim, Abdul. 2006. Analisis Pengaruh Motivasi, Komitmen Organisasi Dan Iklim Organisasi Terhadap Kinerja Pegawai Pada Dinas Perhubungan Dan Telekomunikasi Provinsi Jawa Tengah. JRBI. Vol 2. No 2. Hal: 165-180

James, Gibson. L., et . all. 1996. Organisasi Perilaku, Struktur, Proses, Alih bahasa: Djarkasih. Jakarta : Erlangga

M. Thoha, 2001, Kepemimpinan Dalam Manajemen, Suatu Pendekatan Perilaku, Rajawali Press, Jakarta.

Malthis, R.L dan Jackson. 2001. Manajemen Sumber Daya Manusia. Jakarta: Salemba Empat

Menon, Maria E, 2002, "Perceptions of PreService and In-Service Teachers Regarding the Effectiveness of Elementary School Leadership in Cyprus", The International Journal of Educational Management, 16 February, p.91-97

Muh Su'ud, 2000, "Persepsi Sosial Tentang Kredibilitas Pemimpin", Sinergi Kajian Bisnis dan Manajemen, vol.3, No.1. Hal 51-65 Mulyanto, $\mathrm{H}$ dan Wulandari, A, 2010, Penelitian: Metode dan Analisis, Semarang: CV Agung 
Purnomo Budi Setiyawan dan Waridin (2006) Pengaruh Disiplin Kerja Karyawan dan Budaya Organisasi Terhadap Kinerja di Divisi Radiologi RSUP Dokter Kariadi, Semarang: JRBI. Vol 2. No 2. Hal: 181-198

Rivai, Veithzal. 2004. Manajemen Sumber Daya Manusia Untuk Perusahaan. Jakarta: Rajagrafindo Persada,

Robert, Dale. D. 1992. Pelayan Sebagai Pemimpin. Malang: Gandum Mas.

Suharto dan Budhi Cahyono. 2005. Pengaruh Budaya Organisasi, Kepemimpinan dan Motivasi Kerja Terhadap Kinerja Sumber Daya Manusia di Sekretariat DPRD Propinsi Jawa Tengah. Jurnal Riset \& Bisnis Indonesia, Vol.1, No.1 Sukarno Marzuki, 2002, Analisis Pengaruh Perilaku Kepemimpinan terhadap Kepuasan Kerja dan Kinerja Account Officer : Studi Empirik pada Kantor Cab BRI di Wilayah Jawa Timur, Tesis Program Pasca Sarjana Magister Manajemen Universitas Diponegoro (tidak dipublikasikan) Tampubolon, Biatna. D. 2007. Analisis Faktor Gaya Kepemimpinan Dan Faktor Etos Kerja Terhadap Kinerja Pegawai Pada Organisasi Yang Telah Menerapkan SNI 19-9001-2001. Jurnal Standardisasi. No 9. Hal: 106-115

Utomo, B. 2002. Menentukan Faktorfaktor Kepuasan Kerja dan Tingkat Pengaruh Kepuasan Kerja terhadap Loyalitas Karyawan PT P.Jurnal Manajemen \& Kewirausahaan. Vol. 7 (2). 171-188. 